Anne Kristine Byhring er opptatt av argumentasjon, fagdidaktikk og elev- og studentaktive undervisningstilnærminger. Artikkelen er en del av Anne Kristine Byhrings Ph. D. arbeid ved lærerutdanningen på Norges miljø- og biovitenskapelige universitet (NMBU). Hun har en master i didaktikk og organisasjonslæring fra universitetet i Oslo i 2007, og er nå universitetslektor i naturfagdidaktikk ved barnehagelærerutdanningen på Høgskolen i Oslo.

Erik Knain er professor i realfagdidaktikk ved Seksjon for læring og lærerutdanning ved Norges miljø- og biovitenskapelige universitetet (NMBU). Hans forskningsinteresser omfatter undervisning i komplekse miljøutfordringer, utforskende arbeidsmåter, språk i naturfag og bruk av IKT for tekstlig samhandling. Han har i flere år arbeidet med ulike utviklingsprosjekter i skolen.

Feltarbeidet som ligger til grunn for artikkelen ble gjennomført i aksjonsforskningsprosjektet ElevForsk.

ANNE KRISTINE BYHRING

Department of Mathematical Sciences and Technology (IMT), Norwegian University of Life Sciences, Ås, Norway Anne-Kristine.Byhring@hioa.no

\title{
Framing student dialogue and argumentation: Content knowledge development and procedural knowing in SSI inquiry group work
}

\begin{abstract}
In this article, we discuss the negotiation of the situated common ground in classroom conversations. Decision making on socioscientific issues (SSI) includes norms of diverse funds of knowledge and interests. Arguments and justification may include warrants that cannot necessarily be weighed on the same scale. We discuss Roberts' Visions 1 and 2 of scientific literacy as framing the common ground of classroom discussions. Two teacher-student dialogue sequences with 11th grade students from the Norwegian research project ElevForsk exemplify the negotiation of the situated common ground and the students' deliberations. Our analysis examines what goes on in the thematic content, as well as at the interpersonal level of language use. Further, we suggest that different framings may complement each other and provide a space for the students' emerging scientific conceptual development as well as for deliberation as a form of emerging procedural knowing.
\end{abstract}

\section{INTRODUCTION}

In order to address the development of instructional strategies for group discussions in socioscientific issues (SSI) inquiry, this article discusses the situated common ground for warranting arguments in SSI inquiry. The common ground provides the language resources for justification in a particular situation on the relevant topic. In this article, the situated common ground refers to presuppositions, the shared knowledge, and meaning constructed, construed, and negotiated, depending equally on the speaker and the audience as well as a shared understanding of the default address of communication, i.e., the "mutual knowledge, mutual beliefs, mutual assumptions, and mutual awareness" (Svennevig, 1999, p. 55). A common ground is construed by the participants' framing. A frame-a mutually recognized space of interaction-gives a particular social characterization or shape to a situation and attune the audience to certain elements (Goffman, 1974; Bazerman, 2013). 
Such framing is important to instructional strategies in terms of which aspects of argumentation are foregrounded. Of particular concern is the students' development of content knowledge and the development of the students' collaborative procedural knowing. Procedural knowing is used here to emphasize communal capabilities for proper action and procedure, as distinguished from knowledge seen as capabilities possessed independently by individuals. Accordingly, we discuss two complementary frames for SSI dialogues.

The rhetorical term topoi (Gabrielsen, 2008) refers to "common places", or "topics of invention". The invention concerns finding something to say, thematically, but also in general terms, as for instance, cause and effect, analogies, and comparisons. Science-specific issues provide special topoi on content and participant roles, whereas SSI includes diverse discourses and multiple voices, thus providing content and participant roles providing more general topoi from the public debate. Common ground concerns not only knowledge but also social norms on how teacher and students negotiate meaning. The framing of teacher-student dialogues is a matter of both content and participation.

Basically, what counts as "being scientific" in the classroom is regulated by norms (Knain, 2005). However, SSI inquiry cannot be relegated to the familiar sets of genres or norms that have provided security for generations of science teachers. When teaching science products and procedures, there is a relatively stable set of genres to rely on, for instance the textbook, initiative-response-evaluation (IRE) questioning routine (Mehan, 1979), or the laboratory report. These genres provide a stable common ground, deriving from the culture of academic science reinterpreted and adapted to the school institution. However, SSI is not tied to specific social institutions in any similar manner, but is drawn from rich public discourses. The increasing focus of educational goals on SSI and student participation in classroom debates about controversial issues regards concerns on uncertainties linked to frontier science, as well as to handling diverging values and conflicts of interests (Kolstø, 2001; Sadler, Barab, \& Scott, 2007; Walker \& Zeidler, 2007; Christensen, 2009). This means that the common ground is less likely to be tacitly shared and instead becomes open for negotiation and contestation. Therefore, the framing of dialogue and argumentation in an SSI inquiry should provide room for the development of students' capacities for choice and action and argumentation as a means of procedural knowing.

The teacher's instructional strategies may address the teaching of scientific argumentation (Osborne, 2010). Based on Piaget's thinking, this aspect of argumentation has been prevalent in studies on science education. The importance of dialogue and argumentation in order to promote conceptual learning and to develop students' understanding of argumentation as a critical feature of the nature of science (NOS) has been comprehensively examined (Driver, Asoko, Leach, Mortimer, \& Scott, 1994; Driver, Newton, \& Osborne, 2000; Duchl \& Osborne, 2002; Jimenéz-Alexandre \& Erduran, 2008; Mortimer \& Scott, 2003; Scott, Mortimer, \& Aguiar, 2006).

However, SSI raises questions concerning human behavior, well-being, economics, and social norms. SSI inquiry emphasizes the need for effective decision making and problem solving within a limited amount of time (Simonneaux \& Simonneaux, 2012). In this respect, the primary purpose of argumentation is to deliberate on alternatives, rather than to provide empirical justification of knowledge claims (Byhring, in press).

Our aim is to highlight both the differences and similarities between the different ways of framing dialogue and argumentation in SSI at the classroom interactional level. Our research question is: How can SSI inquiry dialogues make space for both content knowledge development and the capacity and capability for deliberation and decision making?

When focusing on science content knowledge learning, argumentation concerns the warranting and justifying of knowledge claims. The classroom conversation is then based on a relatively firmly framed 
situated common ground. The appropriate ways of what to say and how to do things are familiar to both the teacher and students. In contrast, the second framing may include out-of-school discourses addressing ethical, societal, and economic concerns in the situated common ground, which implies that what should count has to be negotiated to a greater extent. The knowledge claims in SSI cannot necessarily be weighed on the same scale. Rather than agreement and consensus, disagreement and legitimate dissensus may be the norm of deliberative argumentation (Kock, 2007).

In the following we first review several studies focusing on different aspects of inquiry and SSI in order to place our study within the science education discourse. We examine how our perspectives on student argumentation relate to Roberts' Visions 1 and 2 of scientific literacy. Further, the relation between the common ground and warranting of arguments is accounted for. We then present some further theoretical perspectives that may guide the development of teaching approaches aiming at creating a space for the development of both conceptual knowledge and deliberation skills. The two sequences were selected for further analysis to illustrate two different framings of the common ground. It is suggested that the different ways of framing are complementary. SSI inquiry provides a context for situating science content as well as processes.

\section{Theoretical Perspectives}

\section{SSI and the two visions of scientific literacy}

The acquisition of generalized canonical knowledge, scientific facts, and scientific ways of justification is necessary in SSI inquiry, but it is not sufficient (Kolstø, 2001, 2006; Ryder, 2001; Sadler et al., 2007; Zeidler \& Sadler, 2008). Chang Rundgren and Rundgren's (2010) SEE-SEP model is a holistic approach to interdisciplinary SSI content knowledge. They include values and personal experiences as important aspects to stimulate decision making and student skills in argumentation. Østergaard (2012) discusses teacher questioning in Inquiry Based Science Education (IBSE) to stimulate students' qualified guessing in order to help them focus their investigations. Alternating between different instructional strategies may be necessary during the different phases of inquiry. Nussbaum, Sinatra, and Owens (2012) identify argumentation in science classrooms as addressing content as well as social dimensions of scientific work and collaborative inquiry. Their approach to argumentation focuses on dialectical argumentation and students' collaborative construction and critique. They note that students should engage with the "two faces of scientific argumentation": the content and the social angle. According to Borg, Gericke, Höglund, and Bergman (2012), the teaching approaches to SSI and education for sustainable development should include the presentation of different opinions. Overall, instructional strategies that provide pluralistic perspectives to promote dialogue and argumentation are needed in inquiry learning and not least in SSI inquiry.

In distinguishing between science teaching based on Visions 1 and 2 of scientific literacy, Roberts (2007; 2011) emphasizes that Vision 1 provides reasoning patterns based on the practices of science proper, and Vision 2 provides reasoning patterns relevant to science-in-society issues. Vision 1 is rooted in the discipline of science itself and focuses on theoretical reasoning. Vision 2 is rooted in the perspective that science plays a role in human affairs. Roberts relates Vision 2 to the interplay between three different patterns of reasoning: theoretical (theoria), technological (techne), and practical (praxis). The three patterns of reasoning are based on Aristotle's account of the three domains of human purpose, respectively: to understand, to craft, and to make decisions. Roberts perceives all three patterns of reasoning as necessary to be scientifically literate. Vision 1 aims at enculturating students into the science community, whereas Vision 2 aims at developing students' capacities to use and evaluate scientific knowledge, technological problem solving, and personal and public decision-making skills. According to Vision 1, science learners are introduced to science concepts, theories, and models of conventional science, and scientific argumentation is included as part of this process. School science texts, as authoritative sources (Yeo \& Tan, 2009), use the topical resources and language of science. Scientific genres convey the epistemological truths of the discipline as well as the ways in which these 
truths are usually elaborated upon, but also how they are legitimately challenged and questioned (Knain \& Flyum, 2003). In Vision 2, socioscientific knowledge claims appear in diverse shapes and discourses, and an implication of dealing with SSI is the need to be able to handle diverse norms (Kolstø, 2001). We will discuss Visions 1 and 2 as framing the common ground of classroom discussions.

\section{Common ground and warrants}

Common ground is dependent on context and situated negotiation on language use in conversations, expert panels, politics, and public debates, as well as in science classrooms, thus governed by culturally informed contextual constraints (Clyne, Norrby, \& Warren, 2009). The notion of a common ground, to some extent, is the representational parallel to the experiences that Andrée and LagerNyqvist (2012) define as funds of knowledge. Funds of knowledge conceptualize the processes of drawing on experiences, skills, and knowledge from different domains, subject matter domains, and out-of-school knowledge domains. Andrée and Lager-Nyqvist (2012) advocate that teaching approaches should build on students' experiences and funds of knowledge and raise issues of procedure such as construct validity, fair testing, and research ethics. In this way, a common ground can be negotiated and shared. The common ground of classroom discourse thus provides the situated legitimate resources for warranting arguments. In a science inquiry lesson, scientific inquiry procedures and NOS would be an expected common ground for justifying arguments. However, in SSI, an urge for action also provides a common ground for arguments and deliberation (Simonneaux \& Simonneaux, 2012; Kock, 2007).

The situated common ground is a resource for the rational support of arguments. Toulmin (2003) addresses the philosophical choices hidden behind the general premises of argumentation in formal logic. He focuses on the relation between statements of fact and statements of assertion in practical argumentation. Toulmin emphasizes that knowledge claims convey values, theories, and interests, though often as implicit warrants («rules, principles, interference-licenses») (Toulmin, 2003, p. 91). The warrants concern relevance and support the connection between the data and the claim. The preferred warrants are contextual, domain specific, and dependent on the field or group producing the argumentation. Further, the justification of a claim, and thus the soundness and strength of an argument, is retrospective. Justification and evidence are required to support a claim only when it is questioned. The criteria for what counts as justification differ from one field or community to another. The common ground for providing topical resources in complex fields may need to be negotiated (Gabrielsen, 2008).

These negotiations may entail different undertakings in Visions 1 and 2 (Roberts, 2011). For instance, the issue of the rainforest addresses scientific and technological knowledge, but also economy and ethics. Forestry affects the living conditions of local people. Also, the biodiversity of the rainforests may concern students' everyday life, on health (medical product development) and personal welfare, thus rousing commercial interests, environmental interests, and interests of local and indigenous people. During negotiation of the common ground students can draw on various norms. Language uses and appropriate topoi (Gabrielsen, 2008) convey those norms in standardized ways of using language in recurrent situations (Miller, 1994). Hence, identifying genres is an important part of designing SSI teaching. It is important that the situated common ground is open for multiple discourses and perspectives. This calls for deliberative argumentation. In the following we present theoretical perspectives aiming at creating a space for warranting argumentation within the frames of Visions 1 and 2.

\section{Making space}

To a great extent, the framing of the classroom situation depends on the teacher's interventions and the discourse patterns that are established by the teacher. Mortimer and Scott (2003) suggest framing of inquiry dialogues as shifts between interactive and non-interactive moves as well as between authoritative and dialogic communicative approaches. An alternation between teacher-directed autho- 
ritative approaches and dialogic approaches (with multiple voices) creates tension between different explanations and perspectives, providing opportunities for learning. Authoritative approaches aim at developing the science perspective, whereas dialogic approaches aim at giving space and opportunities to use and explore ideas (Scott et al., 2006). By staging and leading the students through the scientific story (Leach \& Scott, 2003), the teacher aims at achieving a common understanding and consensus on the concepts and explanation of phenomena.

Wallace (2004) presented a model for developing scientific literacy in the genres of science. In Wallace's model, exchanges between discipline-based subject matter and students' interests create tensions that are important for students' learning. Successful learning implies that the students use scientific language and genres of science to communicate about science events (Wallace, 2004). Wallace's framework for developing scientific literacy consists of the following factors: (1) authenticity - a dynamic interplay between subject matter, situated authenticity, and student authenticity, whereby students must appropriate scientific language into their own forms of communication; (2) multiple discourses-students need to be exposed to multiple discourses and learn to negotiate between them; and (3) Third space-students must be willing to accept the opportunity to enter a discourse with hybrid language along a continuum between everyday and scientific languages. Different authenticities and multiple discourses create opportunities for transforming semiotic resources into new meanings in a space, where meanings are negotiated, co-constructed, and transformed in light of new experiences. In making a distinction between cultural and personal authenticities, Murphy, Lunn, and Jones (2006) emphasize that the students' negotiation is driven by their sense of personal authenticity, which is the extent to which students find learning experiences personally meaningful and relevant. Multiple discourses (texts and genres) may call for various authenticities in the situated common ground, so that in the third space the participants can negotiate and engage in the dialogue as authentic in terms of their familiarity with the discourse and genre as well as their background knowledge and participant roles. A space for negotiations on the situated common ground can be realized through dialogic communication, not by authoritative communication (Scott et al., 2006).

The theoretical understanding of a problem develops with activity. After all, theoretical knowing is not necessarily universal and decontextualized, but perpetually interchanging with people and technology. Knowing is dynamic and flexible, and dynamic situations in which people construct understanding through social interaction and practical action may be accounted for as emergent problem spaces (Greeno, 1998). This is a relational theory of meaning, which is based on conversation analysis research (Clarke \& Wilkes-Gibbs, 1986; Schegloff, 1991). Constructing the referential meanings of terms is a basic part of the interpretive process and a collaborative achievement by the participants in conversations. The concept of emergent problem spaces draws on theories of social and collaborative knowing in communities of practice as accounted for in theories of situated learning (Brown, Collins, \& Duguid, 1989; Greeno, 1998; Hennessy, 1993; Lave \& Wenger, 1991).

In the following, we will investigate two selected teacher-student dialogue sequences in order to illustrate how a space for negotiation of the common ground is created by the teacher's situated framing. We will discuss the framing of SSI inquiry dialogues addressing Roberts' Visions 1 and 2 of scientific literacy. We emphasize that these examples are selected for analytical purposes; we do not make claims on the typicality of these interactions.

\section{METHOD}

\section{Participants}

The dialogue excerpts presented are with 11th grade general track students from the Norwegian action research project ElevForsk (Students as Researchers in Science Education [StudentResearch]). A traditional school setting framed an open inquiry student project. Teachers and researchers developed instructional strategies to support the implementation of the competence objectives outlined in 
the Norwegian curriculum (Knain \& Kolstø, 2011). The ElevForsk project aimed at providing students with opportunities for exposure to diverse authenticities and multiple discourses. In the context of ElevForsk, inquiry learning refers to the ways of working and thinking that cultivate competencies, such as posing questions and developing answers that are supported by different kinds of evidence. Such evidence may involve data collected by the students themselves, data collected by others, and authoritative texts (Knain \& Kolstø, 2011b). The students were required to choose a topic and an issue to inquire into on the main curriculum area of sustainable development and to include conflicts of interest. Finally, the students submitted a group report on a wiki platform (ElevForsk, 2011).

The episodes presented are led by the same science teacher. Two different groups of students participated. In the first episode, the students worked on formulating a question related to an issue. During the activity, the students sat in groups in the classroom, and the teacher walked between the desks, guiding the groups. The second episode occurred during a student-student group meeting led by the teacher. They discussed the design of a questionnaire to be conducted in the local community.

The group participating in the first episode was particularly focused on data collection from the start due to their choice of topic, the rainforest. Their topic was considered particularly interesting since sustainable development and SSI were given particular emphasis in the overall ElevForsk project. The group participating in the second episode was chosen by the teacher to collaborate with the first group in teacher-guided group meetings. The teacher assembled these groups due to the relevance between issues. The first group chose global climate issues and the second group chose local attitudes toward and effects of $\mathrm{CO}_{2}$ emission control.

\section{Data collection}

Video and audio recordings as well as field notes from classroom observations, audio-recorded interviews with teachers and students, and students' written work on a wiki-space were collected over four years in the ElevForsk project. The two sequences presented are from the fourth year. For analysis of student-student group discussions (Byhring, in press), lesson were chosen on the basis that they were rich in data and had extended dialogues. The student project spanned six weeks and took place in four to five forty-five-minute lessons per week. The two episodes presented here were particularly selected for analysis of teacher-student dialogues. The presentation of the sequences serves to illustrate our discussion of the situated common ground. The episodes were chosen retrospectively from different phases of the inquiry process (Bell et al., 2009).

\section{Analysis}

Our research question calls for analysis and interpretation that connect the individual and the collaborative aspects and that enables us to look at what goes on in the thematic content as well as at the interpersonal level of language use. Our analysis of these episodes is structured according to the analytical categories offered in a framework by Mortimer and Scott: content, communicative approach, patterns of discourse, and teacher interventions (2003, p. 25). We operationalize the categories for our analytical purpose by selected concepts on text and meaning making from Halliday's systemic functional linguistics (Halliday, 2013). Hence, we connect Mortimer and Scott's categories with a theory on text that opens for detailed analysis. First, we use referent chains to trace thematic patterns in the excerpts. Referent chains are strings of words through stretches of text that are "about the same”. Referent chains are analyzed by combining two resources in Halliday's theory for establishing cohesion: reference and lexical cohesion (Halliday, 2013, pp. 605-606). By analyzing referent chains, we trace aspects of both content and patterns of discourse. By considering in addition how meaning is developed between utterances, we are able to address the teacher interventions. From this analysis, we reach conclusions on the communicative approach (Mortimer \& Scott, 2003; Scott et al., 2006). 
Part of the meaning is explicit in language, but inevitably, there are presuppositions that are made, drawing on what is taken to be familiar and shared contextually, that is, the common ground. Our analysis aims at understanding the implicit warrants of argumentation and deliberation by interpreting contextual aspects presupposed in the exchanges among interlocutors, in terms of the categories offered by Mortimer and Scott.

In accordance with our research question, an objective is to identify traces of the situated common ground and the framing that allows for emerging conceptual meaning making and warranting of argumentation, deliberation, and decision making. Our interest is in how the teacher may make space for argumentation addressing both Visions 1 and 2 of scientific literacy.

\section{Two EXAM PLES - The Situated Common Ground of THE SSI INouiRY}

In the first episode, the students read about the rainforest and considered divergent information from two websites. The students asked the teacher for advice. The episode is drawn from a 45-minute lesson and the episode lasted for about one minute. The lesson is chosen from a total of 8 hours and 12 minutes of audio-recorded material from their group work.

There are three important referent chains: Chain 1 is related to the two internet pages. Chain 2 is related to aspects of the rainforest. These two chains were initiated by the students. Chain 3 is started by the teacher in line 07 . There are thus three thematic patterns.

\section{Episode 1}

Table 1. B_1 $(2,3)=$ Boy $1(2,3)$ Short breaks are marked . Somewhat longer breaks . . ; interruption of words: interru-; interruption of speech: interruption of speech_. Overlapping speech: [simultaneously] when more than two people talk at the same time [[simultaneously]]. Comments: ((IN DOUBLE PARENTHESES)). Dialogues are transcribed with a system from Du Bois et al. (1983) as in Svennevig (2009). However, intonation units are not separated in lines. Continuing speech flow from one person is written down continuously.

\begin{tabular}{|l|l|l|l|l|}
\hline Dialogue and referent chains & Chain 1 & Chain 2 & Chain 3 \\
\hline O1 B_1 & $\begin{array}{l}\text { We have a question for you. } \\
\text { We have been reading on } \\
\text { two different pages. There } \\
\text { it says .. eh .. on one page, } \\
\text { it says that the rainforest is } \\
\text { the lungs of the earth, that is, } \\
\text { that it produces more oxygen } \\
\text { than carbon dioxide. And } \\
\text { then it says on another page } \\
\text { that it does not, that is, that } \\
\text { this is just a myth. So, we are } \\
\text { really confused }\end{array}$ & $\begin{array}{l}\text { rainforest - } \\
\text { lungs of the } \\
\text { page }\end{array}$ & $\begin{array}{l}\text { exth - more } \\
\text { oxygen than } \\
\text { carbon dioxide }\end{array}$ & \\
& $\begin{array}{l}\text { And both pages were really } \\
\text { like "reliable" ((HE SAYS 'RELI- } \\
\text { ABLE' IN ENGLISH)) }\end{array}$ & - both pages - & & \\
\hline O2 B_2 & & & \\
\end{tabular}

Table cont. 
Table 1 cont.

\begin{tabular}{|c|c|c|c|c|}
\hline \multicolumn{2}{|c|}{ Dialogue and referent chains } & \multirow{2}{*}{$\begin{array}{l}\text { Chain } 1 \\
\text { regnskog.no } \\
\text { - regnskogfon- } \\
\text { det.no }\end{array}$} & \multirow[t]{2}{*}{ Chain 2} & \multirow[t]{2}{*}{ Chain 3} \\
\hline O3 B_1 & $\begin{array}{l}\text { Like Regnskog.no or Regn- } \\
\text { skogfondet.no, and sort of } \\
\text { like...much like }\end{array}$ & & & \\
\hline 04 B_2 & What should you believe in? & & & \\
\hline O5 B_ & Yeah & & & \\
\hline 06 B_3 & Rainforest- & & rainforest & \\
\hline O7 Teacher & $\begin{array}{l}\text { What have you learnt about } \\
\text { ecosystems? It is a limited } \\
\text { area in nature that to a great } \\
\text { extent manages itself }\end{array}$ & & & ecosystems \\
\hline 08 B_1 & $\begin{array}{l}\ldots \mathrm{mmm} \ldots \text {... but that is also } \\
\text { relevant to }\end{array}$ & & & \\
\hline og Teacher & $\begin{array}{l}\text { So, that means the animals } \\
\text { and the bacteria in the } \\
\text { woods up here }\end{array}$ & & woods & $\begin{array}{l}\text { animals - bac- } \\
\text { teria }\end{array}$ \\
\hline 10 B_1 & Yes & & & \\
\hline 11 Teacher & $\begin{array}{l}\text { They have a metabolism, just } \\
\text { like people, don't they? }\end{array}$ & & & Metabolism \\
\hline 12 B_1 & Yes & & & \\
\hline 13 Teacher & And give off $\mathrm{CO}_{2}$ & & & $\mathrm{CO}_{2}$ \\
\hline 14 B_1 & Mmm & & & \\
\hline 15B_2 & So all the animals in _ & & & \\
\hline 16 Teacher & $\begin{array}{l}\text { It increases then, the concen- } \\
\text { tration of } \mathrm{CO}_{2} \text { increases, and } \\
\text { then all the green plants take } \\
\text { this up and bind it again }\end{array}$ & & green plants & \\
\hline 17 B_1 & Yes & & & \\
\hline 18 Teacher & In photosynthesis & & & photosynthesis \\
\hline
\end{tabular}

The content regards the students' inquiry into different websites. The students refer to claims of knowledge made by the websites. However, the teacher first and foremost directed their focus to the science involved. He addressed scientific concepts and directed them to the relation between metabolism and photosynthesis (line 11, followed up in lines 16 and 18). The teacher shifted the focus from the students' problem with an inquiry into which website to trust, to explaining and presenting them to a scientific argument (lines 7, 9, 11, 13, 16, and 18). Looking closer at the referent chains, chain 1 relates to online resources, while the other two relate to subject matter concepts. Chain 2, on the rainforest as the lungs of the earth, runs parallel to the website pattern. They run from the start initiated by the statement in line 01: "We have a question for you", through line 04: "What should you believe in". The third chain is initiated by the teacher in line 07: "What have you learnt about ecosystems?", starting with ecosystems and ending with photosynthesis. 
The shift in thematic pattern in line 07 divides the episode into two main parts. Other evidence of the shift is a change on the interpersonal level. In the first part the students are talking, in the second part the teacher takes the lead. The episode is staged as a question-answer pattern: The question is phrased in lines 01 to 04 , and the teacher answers in lines 07 to 18 . The teacher's main concern here seems to be scaffolding the students' conceptual understanding of the rainforest as an ecosystem. He reframed the students' question concerning which source to trust and placed the discourse on establishing the scientific ground of Vision 1.

Boy 2's question in line 04 is vital in the SSI contexts associated with Vision 2. The decisive moment for reframing the discourse is in line 07. The teacher's framing by his question to the students has two key features: it has no immediate relation to the question in line 04 , and the teacher immediately started to answer it himself. His intervention was to remind the students of the key scientific idea. Utterances made by the students in this answering part were effectively ignored. What made the teacher's answer relevant to the student's question was that the referent chain about the rainforest as the lungs of the earth stretches into the ecosystems chain in line 9 (animals, bacteria and woods) and in line 17 (green plants and $\mathrm{CO}_{2}$ ). Thus the teacher intervened by listening to the question and then offered a piece of explanation that he deemed important to the students in the situation.

From the above analysis of thematic content, discourse patterns, and intervention, we infer that the communicative approach in this episode was interactive and authoritative. It was interactive since the teacher responded to a question from the students. It was also authoritative since he offered the students a piece of scientific explanation with no actual contribution from the students. The correct explanation from science prevailed. Hence, the science lesson authenticity became foregrounded as the context for providing appropriate topical resources and framed the situated common ground. The teacher framed the content as well as the participant roles. During his presentation of the science content, the teacher paused several times, but the students' short responses were just prompts for the teacher to continue his explanation. The students accepted his framing, as seen from their affirmative comments (lines 10, 12, 14, and 17).

The teacher's intervention provided topical resources by telling a scientific story (Mortimer \& Scott, 2003). He modeled a scientific argument, using the appropriate school science terms. The students asked for guidance on how to inquire further into their chosen issue, so they may also have interpreted the teacher's guidance as an implicit call to critically consider their sources. In their final report, the students did not refer to the website that used the metaphor of the rainforest as the lungs of the earth.

To sum up, the teacher shifted the focus by offering theoretical reasoning, in line with Roberts' Vision 1. Undeniably, conceptual understanding is important in science education, and the teacher's modelling of a scientific explanation to the students has a legitimate place in SSI teaching. However, the common ground provided by the scientific exposition genre narrowed the discourse by positioning the students as receivers of knowledge rather than as inquirers into a question. In fact, Boy 2's initial question (line 04) was a call for criteria for choosing between the two websites: "What should you believe in?" This question has no prior answer, and a decision would require an examination of different perspectives.

The students were exposed to various out-of-school discourses and genres through their web searching and questioned the reliability of sources. Their initiative called for a space for collaboration and deliberation, but the teacher did not use the opportunity of the uncertainty that had emerged to address, for instance, genre, publisher, ideology, or adaptation to the audience. In the framing of the dialogue, the teacher excluded the societal discourse. Out-of-school contexts were transmuted into classroom tasks (Andrée \& Lager-Nyqvist, 2012). 
The next episode involved the students engaging in their own investigations. They planned interviews with members of the local community. In this situation, the teacher adopted a different strategy resulting in a different framing. The episode lasted for a couple of minutes, during a teacher-guided student-student group meeting about 18 minutes long.

In the following episode, we have identified four referent chains. They represent interwoven thematic patterns, which we have grouped into two pairs. Chains 1 and 2 are on the questionnaire. Chains 3 and 4 are on busses and their use of energy. Further, the term "environmentally friendly", introduced by a student in line 07 , is repeated and discussed.

\section{Episode 2}

Table 2. $B \_A(B, C)=\operatorname{Boy} A(B, C) ; G \_A(B)=\operatorname{Girl} A(B)$

\begin{tabular}{|c|c|c|c|c|c|}
\hline \multicolumn{2}{|c|}{ Dialogues and referent chains } & \multirow{2}{*}{$\begin{array}{l}\text { Chain } 1 \\
\text { interview - } \\
\text { questions - }\end{array}$} & \multirow{2}{*}{\begin{tabular}{|l|} 
Chain 2 \\
them - \\
you
\end{tabular}} & \multirow[t]{2}{*}{ Chain 3} & \multirow{2}{*}{\begin{tabular}{|l|} 
Chain 4 \\
Public \\
.. eh \\
trans- \\
port -
\end{tabular}} \\
\hline 01 Teacher & $\begin{array}{l}\text { Interview them about some } \\
\text { knowledge. And then I think that } \\
\text { one could develop some questions } \\
\text { about the future ... Would .. you } \\
\text {.. change your attitude to the use } \\
\text { of. public .. eh transport if .. or } \\
\text { something }\end{array}$ & & & & \\
\hline O2 G_A & $\begin{array}{l}\text { But we did have that. If . . eh, this } \\
\text { becomes .. eh }\end{array}$ & that & & & \\
\hline O3 B_A & Environmentally friendly & & & & \\
\hline O4 G_A & $\begin{array}{l}\text { Environmentally friendly; would } \\
\text { you use the bus then? }\end{array}$ & & you & & the bus \\
\hline O5 Teacher & $\begin{array}{l}\text { Yes. Environmentally friendly is a } \\
\text { somewhat vague concept .. isn't it? } \\
\text { Don't you agree? }\end{array}$ & & & & \\
\hline 06 B_A & $\begin{array}{l}\text { What do you mean? I think it is } \\
\text { quite clear whether a bus is envi- } \\
\text { ronmentally friendly or not }\end{array}$ & & & & a bus \\
\hline 07 G_A & $\begin{array}{l}\text { Then it runs on hydrogen or biogas } \\
\text { or_ }\end{array}$ & & & $\begin{array}{l}\text { hydrogen - } \\
\text { biogas }\end{array}$ & it \\
\hline 08 B_A & $\begin{array}{l}\text { It may be environmentally friendly } \\
\text { even if it runs on petrol too, if it } \\
\text { only emits little, kind of }\end{array}$ & & & petrol & $\begin{array}{l}\text { it }- \text { it } \\
- \text { it }\end{array}$ \\
\hline O9 G_B & Yes, yes ((AGREES)) & & & & \\
\hline
\end{tabular}

Table cont. 
Table 2 cont.

\begin{tabular}{|c|c|c|c|c|c|}
\hline \multicolumn{2}{|c|}{ Dialogues and referent chains } & \multirow{2}{*}{$\begin{array}{l}\text { Chain } 1 \\
\text { question }\end{array}$} & \multirow[t]{2}{*}{ Chain 2} & \multirow{2}{*}{$\begin{array}{l}\text { Chain } 3 \\
\text { zero emis- } \\
\text { sion stuff }\end{array}$} & \multirow{2}{*}{$\begin{array}{l}\text { Chain } 4 \\
\text { it }\end{array}$} \\
\hline 10 B_A & $\begin{array}{l}\text { But we can deepen the question a } \\
\text { bit, and write if it had been driving } \\
\text { on zero emission stuff, then ... sort } \\
\text { of }\end{array}$ & & & & \\
\hline 11 Teacher & .. yes, and what & & & & \\
\hline 12 B_A & $\begin{array}{l}\text { That does not pollute anything at } \\
\text { all }\end{array}$ & & & that & \\
\hline 13 Teacher & $\begin{array}{l}\text { Yes, and you think that the man in } \\
\text { the street has knowledge about } \\
\text { that [laughs a little bit] }\end{array}$ & & $\begin{array}{l}\text { the man } \\
\text { in the } \\
\text { street }\end{array}$ & & \\
\hline 14 B_A & Yes & & & & \\
\hline 15 Teacher & $\begin{array}{l}\text { They must know something about } \\
\text { emission }\end{array}$ & & they & emission & \\
\hline 16 B_B & $\begin{array}{l}\text { [simultaneously] They do know the } \\
\text { difference between emission, zero } \\
\text { emission, and some emission }\end{array}$ & & they & $\begin{array}{l}\text { emission - } \\
\text { zero emis- } \\
\text { sion - } \\
\text { emission }\end{array}$ & \\
\hline $17 G_{-} B(?)$ & .. emission .. ((MUMBLING)) & & & & \\
\hline 18 B_A & I think most people know & & $\begin{array}{l}\text { most } \\
\text { people }\end{array}$ & & \\
\hline 19 Teacher & $\begin{array}{l}\text { I am not quite sure about that } \\
\text { myself. You have just been through } \\
\text { Energy for the Future, so your } \\
\text { insight into this is good }\end{array}$ & & & & \\
\hline $20 B_{-} A$ & Yes, right & & & & \\
\hline $21 \mathrm{G} \_B$ & $\begin{array}{l}\text { But if it says zero emission, then } \\
\text { [I?] don't understand }\end{array}$ & it & & $\begin{array}{l}\text { zero emis- } \\
\text { sion }\end{array}$ & \\
\hline 22 & $\begin{array}{l}\text { [[they talk simultaneously and } \\
\text { mumble]] ((INAUDIBLE)) }\end{array}$ & & & & \\
\hline 23 B_C & It is even written on the busses & & & & buses \\
\hline 24 B_B & $\begin{array}{l}\text { But they sort of know, if they are } \\
\text { told. This bus does not emit } \mathrm{CO}_{2} \text {. } \\
\text { Then they know that there is no } \\
\mathrm{CO}_{2} \text { emission }\end{array}$ & & $\begin{array}{l}\text { they } \\
\text { - they - } \\
\text { they }\end{array}$ & $\begin{array}{l}\mathrm{CO}_{2} \text { - emis- } \\
\text { sion }\end{array}$ & bus \\
\hline 25 Teacher & Yes, it's OK & & & & \\
\hline 26 B_A & $\begin{array}{l}\text { Then we could change it a bit, } \\
\text { write it a little more precisely in } \\
\text { the last question }\end{array}$ & question & & & \\
\hline
\end{tabular}


The teacher addressed the crafting of the questionnaire. The critical turn is line 05 , where he questions the term environmentally friendly. In line 13, he challenges the students on audience awareness, and he raises doubt in line 19.

The repetition of the adjective environmentally friendly is important, since it sets off an inquiry into what an environmentally friendly bus is. The students grappled with the theme in two different contexts. In the first place, in the school context situation (what characterizes environmentally friendly busses according to use of energy) (line 19). In the second place, in the context of interviewing lay people, the students need to operationalize this "vague concept" (as expressed by the teacher in line 5). This concerns how the term is commonly used by lay people. The students need to interpret the responses from the interviewees.

Compared to episode 1, here, no referent chains were "owned" by the teacher. In his three significant turns (01, 05, and 19) he asked open questions and expressed doubt, on behalf of the interviewees (10) and on the students' understanding, expressed subjectively ("I") and hedged ("not quite sure") (19). This interaction pattern we label sustaining inquiry. From the above we label the teacher's interventions shaping ideas (Mortimer \& Scott, 2003, p. 45). The teacher is opening and keeping open a space for sustained inquiry. It follows from the pattern of discourse and the teacher's intervention that the communicative approach is interactive and dialogic "in that the teacher listens to, and takes account of the students' point of view" (p. 36). The teacher's interventions stimulated the students to take critical initiatives (line 16 and 23). The teacher's intention seems to be to find a formulation that can communicate the notion of environmentally friendly effectively to the interviewees. In fact, the teacher did not intervene in order to clarify the scientific concepts, even if supporting the students' conceptual development could also have been an obvious approach in this situation.

The driving forces of the conversation between the teacher and the students are the authentic constraints of designing a questionnaire at the intersection of science concepts and lay knowledge. Another authentic constraint is their need for the questionnaire to provide valid and reliable data. The deliberation on which term is appropriate is supported by warranting from a situated common ground consisting of a diversity of discourses, including school science, as well as technical and layman public discourses. The referent chains may be viewed as traces of these topical resources. The teacher's dialogic approach keeps the third space open and allows for a wide range of topical resources.

The framing of this learning situation opened up for the participation of different points of view and allowed the students to voice their ideas and perspectives (Scott et al., 2006), and these included how "plain folks" (Brown et al., 1989) speak about and understand the wording environmentally friendly. This attempt to adapt to the audience made the students negotiate the situated common ground.

By questioning the students' choices, the teacher provided opportunities for them to exercise inventive and critical thinking skills in an emergent problem space (Greeno, 1998). The discussion between the teacher and the students may be viewed as a negotiation of the situated common ground. The framing here may serve the purposes of both of Robert's Visions. However, the context of schooling (Schleppegrell, 2001) was, perhaps, in the end, the dominant situated common ground. In the end, the students chose the precise scientific expression, $\mathrm{CO}_{2}$ emission (lines 24 and 26).

\section{DISCUSSION}

The dialogue sequences illustrate two different ways of framing student argumentation in an SSI inquiry: 1) The negotiation of the situated common ground is framed by science-subject conceptual knowledge and participant roles, with roles defined as someone possessing knowledge and others who do not. 2) The negotiation of the situated common ground draws on broader topical resources 
and a diversity of knowledge domains from the public debate. In the first episode, the students asked a question about which website to trust, opening for a complex negotiation of criteria for trusting a source, framing the conversation within the realm of Vision 2, since "trust" is a less-defined issue than the question of what is correct knowledge or not. However, the teacher transformed this into questions of understanding scientific concepts, moving the issue into the practices of learning established scientific knowledge in the realm of Vision 1 addressing theoretical patterns of reasoning. This shift in thematic pattern was not a complete break. However, it was a fundamental shift in the interpersonal aspect. He could also have supported the students in recognizing the need to address the validity of the knowledge claims made by the different websites, and he could have addressed practical and technical concerns in line with Roberts' Vision 2. However, the teacher's authoritative approach did not make space for the students to experience this need. The teacher modeled the scientific argument about the ecosystem and photosynthesis. We note that when interpreting the situation as a matter of recalling conceptual knowledge, through his authority, the teacher simultaneously closed the third space that had been potentially created by the students' initial question. The teacher could have facilitated the students' identification and negotiation of common ground by including different authenticities, e.g., science subject matters, non-governmental organization (NGO) websites, and students' personal experiences, and individual interests, for instance by taking up the term "reliable" used by one of the students. The opportunity for authentic inquiry into which website to trust was then lost, at least temporarily.

The different ways of framing complement rather than oppose each other, as both authoritative and dialogic approaches are needed in teaching. Furthermore, we should acknowledge that capturing all aspects of Vision 2, scientific and social, alternating authoritative and dialogic approaches in one and the same guiding session, may be impractical and possibly unwise. However, in the first episode (line 04), the teacher did not offer any explicit reasons for his exposition and how it related to the student's initial question or why they would need it. Therefore, the intervention resulted in a marked shift in common ground by both content and participant roles. For the teacher, the importance of establishing the scientific connections may be very obvious, but likely not for the students.

The data are not extensive enough to support inferences about the appropriateness of different frames to the different phases of the inquiry process, but it is interesting to notice that in this early phase, the teacher chooses to frame the discussion first and foremost within the science subject discourse, while later he made efforts to open up a space for negotiation and deliberation between discourses. It is also interesting to notice the closing lines in episode 2. The teacher finally accepted the student's choice (line 25), which may be more in line with Vision 1 than with Vision 2.

Related to Vision 2, practical, technical, and theoretical reasoning patterns are not only useful but necessary for decision making and action. The teacher's questioning in the second episode challenged the students' procedural knowing and crafting skills regarding the design of a questionnaire. The teacher's strategy allowed for the participation of multiple discourses by including plain folks' talk, and students' experiences, as well as school science. The appropriate concepts emerged in context and relative to a particular situation and audience. According to Greeno (1998), the referential meanings may be characterized as relations between situations, rather than as properties of symbolic expressions (p. 9). Consequently, the meaning of the concepts that are appropriate in any particular situation becomes a relation between the situation where someone talks and the situation to which the utterance is interpreted as referring. The criteria that constitute a common ground may be part of what is negotiated in the process of meaning making. In deliberative argumentation, associated with Vision 2, the teacher needs to support the students in this process, for instance, by sorting out what are the ethical, political, or scientific aspects of the inquiry and whether the purposes of the discussion relate to content, collaboration, or crafting, for instance the design of a questionnaire or a report (Byhring, in press). 
Deliberation is learned through enculturation both in school science settings and in out-of-school settings, where different funds of knowledge are developed and drawn from. Members of a culture share ways of referring to and talking about phenomena. From a science education perspective, Driver et al. (1994) call this informal ways. Informal ways of talking may convey other warrants than those from scientific perspectives. To gain a broader understanding of the complexity involved in SSI, students need guidance and teacher support in discussions and carefully planned teacher presentation and modeling. Further research should explore and examine teachers' alternation between strategies and identify effective approaches to the different aspects of argumentation that has been presented. Learning environments should provide students with opportunities to create a space for the complexity of concepts and issues to emerge. They should also provide students with opportunities to deliberate on procedures and to inquire into different genres, in order to stimulate skills in decision making aiming at authentic civic engagement.

\section{REFERENCES}

Andrée, M., \& Lager-Nyqvist, L. (2012). "What do you know about fat?" Drawing on diverse funds of knowledge in inquiry based science education. NorDiNa, 8(2), 178-193.

Bazerman, Ch. (2013). A Rhetoric of Literate Action: Literate Action, Volume 1. Perspectives on Writing. Fort Collins, Colorado: The WAC Clearinghouse and Parlor Press.

Byhring, A. K. (in press). Characteristics and functions of sixteen-year-old students' collaborative deliberation when working with socioscientific inquiry assignments. Journal of Argumentation in Context.

Bell, T., Urhane, D. Schanze, S., \& Ploetzner, R. (2009). Collaborative inquiry learning Models, tools and challenges. International Journal of Science Education, 32(3), 349-377.

Borg, C., Gericke, N., Höglund, H-O., \& Bergman, E. (2012). The barriers encountered by teachers implementing education for sustainable development: Discipline bound differences and teaching traditions. Research in Science \& Technological Education, 3o(2), 185-207.

Brown, J. S., Collins, A., \& Duguid, P. (1989). Situated cognition and the culture of learning. Educational Researcher, 18(1), 32-42.

Chang Rundgren, S-N., \& Rundgren, C-J. (2010). SEE-SEP: From a separate to a holistic view of socioscientific issues. Asia-Pacific Forum on Science Learning and Teaching, 11, 1, 1-24.

Christensen, C. (2009). Risk and school science education. Studies in Science Education, 45(2), 205223.

Clarke, H. H., \& Wilkes-Gibbs, D. (1986). Referring as a collaborative process. Cognition, 22, 1-39.

Clyne, M., Norrby, C., \& Warren, J. (2009). Language and Human Relations. Styles of Address in Contemporary Language. New York, NY: Cambridge University Press.

Driver, R., Asoko, H., Leach, J., Mortimer, E. F., \& Scott, P. H. (1994). Constructing scientific knowledge in the classroom. Educational Researcher, 23(7), 5-12.

Driver, R., Newton, P., \& Osborne, J. (2000). Establishing the norms of scientific argumentation in classrooms. Science Education, 84, 287-312.

Duchl, R. A., \& Osborne, J. (2002). Supporting and promoting argumentation discourse in science education. Studies in Science Education, 38, 39-72.

ElevForsk (2011). http://interessekonflikter.umb-sll.wikispaces.net/ (retrieved May 25, 2014)

Gabrielsen, J. (2008). Topik. Ekskursioner i retorikkens toposlære. Åstorp: Retorikforlaget.

Greeno, J. G. (1998). The situativity of knowing, learning and research. The American Psychologist, $53(1), 5^{-26 .}$

Goffman, E. (1974). Frame Analysis: An Essay on the Organization of Experience. Boston: Northern University Press

Halliday, M. A. K. (2013). Halliday's introduction to functional grammar. Revised by C.M.I.M Matthiessen. London: Routledge.

Halliday, M. A. K., \& Hasan, R. (1985). Language, Context, and Text: Aspects of Language in a Social-semiotic Perspective. Geelong: Deakin University Press.

Hennessy, S. (1993). Situated cognition and cognitive apprenticeship: Implications for classroom 
learning. Studies in Science Education, 22, 1-41.

Jimenéz-Aleixandre, M. P., \& Erduran, S. (2008). Argumentation in science education: An overview. In S. Erduran \& M. P. Jimenéz-Aleixandre (Eds.), Argumentation in Science Education: Perspectives from Classroom-based Research (pp. 3-27). Philadelphia, PA: Springer.

Knain, E. (2005). Identity and genre literacy in high-school students' experimental reports. International Journal of Science Education, 27(5), 607-624.

Knain, E., \& Flyum, K. H. (2003). Genre as a resource for science education. The history of the development of the experimental report. In K. Fløttum \& F. Rastier (Eds.), Academic Discourse. Multidisciplinary Approaches. Oslo: Novus Press.

Knain, E., \& Kolstø, S. D. (Eds.). (2011). Elever som forskere i naturfag. Oslo: Universitetsforlaget.

Knain, E., \& Kolstø, S. D. (2011b). Utforskende arbeidsmåter-en oversikt. In E. Knain \& S. D. Kolstø (Eds.), Elever som forskere i naturfag (pp. 127-163). Oslo: Universitetsforlaget.

Kock, C. (2007). Norms of legitimate dissensus. Informal Logic, 27(2), 179-196.

Kolstø, S. D. (2001). Scientific literacy for citizenship: Tools for dealing with the science dimension of controversial socioscientific issues. Science Education, 85(3), 291-310.

Kolstø, S. D. (2006). Patterns in students' argumentation confronted with a risk-focused socio-scientific issue. International Journal of Science Education, 28(14), 1689-1716.

Lave, J., \& Wenger, E. (1991). Situated Learning: Legitimate Peripheral Participation. Cambridge: Cambridge University Press.

Leach, J., \& Scott, P. H. (2003). Individual and sociocultural views of learning in science education. Science \& Education, 12(1), 91-113.

Mehan, H. (1979). "What time is it, Denise?”: Asking known information questions in classroom discourse. Theory into Practice, 18(4), 284-294).

Miller, C. R. (1994). Genre as social action. In A. Freedman \& P. Medway (Eds.), Genre and the New Rhetoric (pp. 23-42). London: Taylor \& Francis.

Mortimer, E. F., \& Scott, P. H. (2003). Meaning Making in Secondary Science Classrooms. Buckingham: Open University Press.

Murphy, P., Lunn, S., \& Jones, H. (2006). The impact of authentic learning on students' engagement with physics. The Curriculum Journal, 17(3), 229-246. doi: 10.1080/09585170600909688

Norris, S. P. (1995). Learning to Live with Scientific Expertise: Toward a Theory of Intellectual Communalism for Guiding Science Teaching. Science Education, 92(2), 210-217.

Nussbaum, E. M., Sinatra, G. M., \& Owens, M. C. (2012). The two faces of scientific argumentation: Applications to global climate change. In M. S. Khine (Ed.), Perspectives on Scientific Argumentation (pp. 17-37). New York: Springer.

Osborne, J. (2010). Arguing to learn in science: The role of collaborative, critical discourse. Science, $328,463-466$.

Ramage, J., Callaway, M., Clary-Lemon, J., \& Waggoner, Z. (2009). Argument in Composition. West Lafayette, In: Parlor Press.

Roberts, D. A. (2007). Scientific literacy/Science literacy. In S. K. Abell \& N. G. Lederman (Eds.), Handbook of Research on Science Education (pp. 729-780). Mahwah, NJ: Lawrence Erlbaum Associates.

Roberts, D. A. (2011). Competing visions of scientific literacy: The influence of a science curriculum policy image. In C. Linder, L. Östman, D. A. Roberts, P-O. Wickman, G. Erickson, \& A. MacKinnon (Eds.), Exploring the Landscape of Scientific Literacy (pp. 11-27). New York, NY: Taylor \& Francis.

Ryder, J. (2001). Identifying science understanding for functional scientific literacy. Studies in Science Education, 36, 1-44.

Sadler, T. D., Barab, S. A., \& Scott, B. (2007). What do students gain by engaging in socioscientific inquiry? Research in Science Education, 37, 371-391.

Schegloff, E. A. (1991). Conversation analysis and socially shared cognition. In L. B. Resnick, J. M. 
Levine, \& S. D. Teasley (Eds.), Perspectives in Socially Shared Cognition (pp. 150-170). Washington, D.C.: American Psychological Association.

Schleppegrell, M. J. (2001). Linguistic features of the language of schooling. Linguistics and Education, 9, 49-67.

Scott, P. H., Mortimer, E. F., \& Aguiar, O. G. (2006). The tension between authoritative and dialogic discourse: A fundamental characteristic of meaning making interactions in high school science lessons. Science Education, 9o(4), 604-631.

Simonneaux, J., \& Simonneaux, L. (2012). Educational configurations for teaching environmental socioscientific issues within the perspective of sustainability. Research in Science Education 42(1): 75-94.

Svennevig, J. (1999). Getting Acquainted in Conversation: A Study of Initial Interactions. Philadelphia, PA: John Benjamins Publishing Company.

Svennevig, J. (2009). Språklig samhandling: Innføring i kommunikasjonsteori og diskursanalyse. Oslo: Cappelen.

Toulmin, S. E. (2003). The Uses of Argument. Cambridge: Cambridge University Press.

Walker, K. A., \& Zeidler, D. L. (2007). Promoting discourse about socioscientific issues through scaffolded inquiry. International Journal of Science Education, 29(11), 1387-1410.

Wallace, C. S. (2004). Framing new research in science literacy and language use: Authenticity, multiple discourses, and the "third space." Science Education, 88(6), 901-914.

Yeo, J., \& Tan, S. C. (2010). Constructive use of authoritative sources in science meaning-making. International Journal of Science Education, 32(13), 1739-1754.

Zeidler, D. L., \& Sadler, T. D. (2008). The role of moral reasoning in argumentation: Conscience, character, and care. In S. Erduran \& M. P. Jiménez-Aleixandre (Eds.), Argumentation in Science Education (pp. 201-216). Philadelphia, PA: Springer.

Østergaard, L. D. (2012). Inquiry based science education og den sociokulturelt forankrede dialog i naturfagsundervisningen. NorDiNa, 8(2), 162-177. 